\title{
BMJ Open Clinicopathological analysis of 5146 eyelid tumours and tumour-like lesions in an eye centre in South China, 2000- 2018: a retrospective cohort study
}

\author{
Linyan Wang (D , , ${ }^{1,2}$ Yi Shan (D) , ${ }^{1}$ Xizhe Dai, ${ }^{1}$ Na You, ${ }^{3}$ Ji Shao, ${ }^{1}$ Xiangji Pan, ${ }^{1}$ \\ Tao Gao, ${ }^{1}$ Juan $Y e$ (D) ${ }^{1}$
}

To cite: Wang L, Shan Y, Dai X, et al. Clinicopathological analysis of 5146 eyelid tumours and tumour-like lesions in an eye centre in South China, 2000-2018: a retrospective cohort study. BMJ Open 2021;11:e041854. doi:10.1136/ bmjopen-2020-041854

- Prepublication history for this paper is available online. To view these files, please visit the journal online (http://dx.doi. org/10.1136/bmjopen-2020041854).

Received 19 June 2020 Revised 01 December 2020 Accepted 07 December 2020

Check for updates

(C) Author(s) (or their employer(s)) 2021. Re-use permitted under CC BY-NC. No commercial re-use. See rights and permissions. Published by BMJ.

${ }^{1}$ Department of Ophthalmology, Zhejiang University School of Medicine Second Affiliated Hospital, Hangzhou, China 2Department of Ophthalmology, University of California San Francisco, San Francisco, California, USA

${ }^{3}$ Hengdian Wenrong Hospital, Jinhua, China

Correspondence to

Professor Juan Ye;

yejuan@zju.edu.cn

\section{ABSTRACT}

Objectives To describe the clinicopathological

characteristics of patients with eyelid tumours and tumour-like lesions in South China, investigate possible factors affecting tumour constitution.

Design Retrospective cohort study.

Setting All patients diagnosed with eyelid tumours were included from a high-volume tertiary eye care centre from South China which caring for over 2000 patients per day. All biopsied specimens were reviewed by two senior pathologists and were classified according to the fourth edition of the WHO Classification of Skin Tumours.

Participant A total of 5146 cases of eyelid lesions were reviewed from 2000 to 2018, being classified by histogenesis and pathologic diagnosis, being compared with data from previous literature containing different races.

Main outcome measures Age-specific and genderspecific incidence constitutions, time trends, tumour location, distribution in different age groups and relationship with Sociodmographic Index (SDI) were calculated.

Results Benign tumours accounted for $85.08 \%$ (4378) of all cases, among which, nevus was most common (33.07\%). Eight of top 10 benign lesions had higher occurrence in upper eyelids. The $R^{2}$ value of linear regression in patient annual number of benign lesions were $0.946(p<0.01)$ for male and $0.914(p<0.01)$ for female. More than $33.60 \%$ (1471/4378) were made up by patients younger than 40 years. The number of patients undergoing removal of benign lesions decreased with age. Among the malignant lesions, basal cell carcinoma (BCC) was most prevalent (48.70\%), followed by sebaceous gland carcinoma (34.24\%) and majority $(81.8 \%)$ occurred in patients above 60 years. Conclusions Over the past 19 years, most eyelid tumours occurred at our centre were benign lesions. The number of patients presenting with benign lesions increased in both genders, especially among young females who were more likely to request surgeries. Among malignant lesions, $\mathrm{BCC}$ remains the most common type, appears a higher incidence in countries with higher SDI.

\section{INTRODUCTION}

A total of $5 \%-10 \%$ of skin cancers occur on the eyelids. ${ }^{2}$ Even though the clinical
Strengths and limitations of this study

- This is the first large-scale clinicopathological analysis of eyelid tumours of South China in recent decades, also is one of the largest-scale studies worldwide.

- Unlike previous cross-sectional studies, our study included longitudinal changes for over 19 years.

- We first established the possible relationship between the constitution of malignant eyelid tumours and Sociodemographic Index.

- The patients recruited from a single centre could not represent the real tumour morbidity and epidemic characteristics of the entire community population.

presentations of eyelid tumours has been widely reported, misdiagnosis and missed diagnosis by clinicians occur frequently. ${ }^{2}{ }^{3}$ The correct diagnosis of eyelid tumours is of vital importance in determining management strategies. ${ }^{4}$ Eyelids play an important role in protecting the ocular surface as well as in facial aesthetics. Prompt diagnosis and treatment of malignant eyelid tumours are essential in preventing intraorbital and intracranial extension and/or systemic spread. Therefore, early recognition and precise pathological diagnosis of eyelid tumours cannot be overemphasised.

Most previous studies have focused on malignant eyelid tumours ${ }^{5-7}$ with little attention to benign eyelid tumours. However, some malignant lesions may masquerade as benign lesions leading to misdiagnosis. ${ }^{8}$ Additionally, small sample size and inadequate demographic information have been limitations to earlier studies on eyelid tumours. ${ }^{9-13}$ Previous large studies from North China employed an old histological classification system, while reports from South China focused on cases presenting between 1953 and 1992. ${ }^{14-17}$ 
The purpose of this large-scale study is to describe the clinicopathological analysis of eyelid neoplasms and to provide a better understanding of epidemiological and clinical characteristics of eyelid tumours in South China. Besides, make an informative literature review of different countries and races, hoping to figure out the possible factors resulted in the variations of tumour spectrum and benefit future investigations of the pathogenesis.

\section{METHODS}

This study was conducted in the Ophthalmology Department of the Second Affiliated Hospital, Zhejiang University School of Medicine (ZJU-2). The Ophthalmology Department at ZJU-2 is one of the high-volume tertiary eye care centres in China caring for 800000 patients annually and with referrals from neighbouring Provinces like Jiangxi and Anhui.

This is a retrospective study with the following inclusion and exclusion criteria. All patients who had eyelid surgery because of tumorous lesions between January 2000 and December 2018 were retrospectively reviewed. Patients who did not have histopathology report or only have uncertain diagnosis (fewer than 1\%) were excluded from the study. And all biopsied specimens were reviewed by two senior pathologists and were classified according to the fourth edition of the WHO Classification of Skin Tumours. ${ }^{18}$ Patient demographic data, medical history, tumour site, size, tumour morphology and histopathological findings were extracted from the medical record and analysed.

We also reviewed previous reports about eyelid tumours to make comparisons of tumour constitution and its relationship with socioeconomic development which is evaluated by Sociodemographic Index (SDI). SDI was a comprehensive measure of the level of development of each country based on per capita income levels, average educational attainment and total fertility rate (ranged from 0 to 1, the higher indicates better socio-demographic development. All SDI data were recruited from Global Burden of Disease Study (http://ghdx.healthdata.org/ record/ihme-data/gbd-2015-socio-demographic-indexsdi-1980\%E2\%80\%932015, last accessed on December 2019).

Data analysis was performed using SPSS V.23.0 (IBM). Descriptive statistics were presented as frequencies and percentages. Student's t-test was used to assess associations between categorical variables. A $\mathrm{p}<0.05$ was considered significant. Linear regression was used to analyse trends over time.

\section{Patient and public involvement}

Patients or the public were not involved in the design, or conduct, or reporting, or dissemination plans of our research.

\section{RESULTS}

\section{Overall analysis}

A total of 5146 biopsy proven eyelid tumours were analysed of which $4378(85.1 \%)$ cases were benign eyelid tumours, and 768 (14.9\%) were malignant eyelid tumours. All patients were Chinese with a higher female preponderance $(61.4 \%)$. The mean age at diagnosis was 52.8 \pm 19.7 years (range 1-106 years). Seventy-three per cent of all cases were 40 years of age or above. The mean age of patients with benign eyelid tumours was $49.6 \pm 18.8$ years and $71.2 \pm 13.9$ years for the malignant. The age difference between them was statistically significant $(\mathrm{p}<0.001) .49 .7 \%(2178 / 4178)$ of benign lesions and $52.3 \%(402 / 768)$ malignant cases occurred in right eye. There was no significant difference of laterality of left or right eye in all cases $(p=0.199)$. The overall distribution of the benign and malignant eyelid tumours was summarised in table 1.

\section{Classification based on histogenesis}

Tumours of epidermal origin were the most common (39.5\%), followed by melanocytic tumours $(28.6 \%), 514$ $(10.0 \%)$ adnexal tumours, $364(7.1 \%)$ tumours of mesenchymal origin, $21(0.4 \%)$ tumours of lymphoid origin, 16 $(0.3 \%)$ tumours of neural origin and $726(14.1 \%)$ other tumours. The independent results of Malignant and Benign ones were figure 1. Melanocytic origin $(33.1 \%$, $1448 / 4378$ ) was the most common origin of benign lesion whereas over half of malignant tumours originated from epithelial tissue $(61.1 \%, 469 / 768)$.

\section{Classification by pathological diagnosis}

Demographic data and clinicopathological types of benign and malignant eyelid tumours are shown in table 2. For benign lesions, there are nearly 40 types of diseases. Among 4378 benign tumours or tumour-like lesions, nevus was the most common $(1448,33.07 \%)$ type, followed by squamous cell papilloma $(539,12.31 \%)$ and basal cell papilloma (418, 9.55\%). Among 768 malignant

Table 1 Characteristics of 5146 eyelid tumours in an eye centre in South China 2000-2018

\begin{tabular}{|c|c|c|c|c|c|c|c|c|c|}
\hline \multirow[b]{2}{*}{ Tumour type } & \multicolumn{3}{|l|}{ Male } & \multicolumn{3}{|l|}{ Female } & \multicolumn{3}{|l|}{ Total } \\
\hline & Cases & Percentage & $\begin{array}{l}\text { Age (year) } \\
\text { mean } \pm S D\end{array}$ & Cases & Percentage & $\begin{array}{l}\text { Age (year) } \\
\text { mean } \pm S D\end{array}$ & Cases & Percentage & $\begin{array}{l}\text { Age (year) } \\
\text { mean } \pm S D\end{array}$ \\
\hline Malignant & 353 & 6.9 & $71.6 \pm 13.6$ & 415 & 8.1 & $70.9 \pm 14.1$ & 768 & 14.92 & $71.2 \pm 13.9$ \\
\hline Total & 1986 & 38.6 & $55.0 \pm 21.0$ & 3160 & 61.4 & $51.5 \pm 18.8$ & 5146 & 100 & $52.8 \pm 19.7$ \\
\hline
\end{tabular}




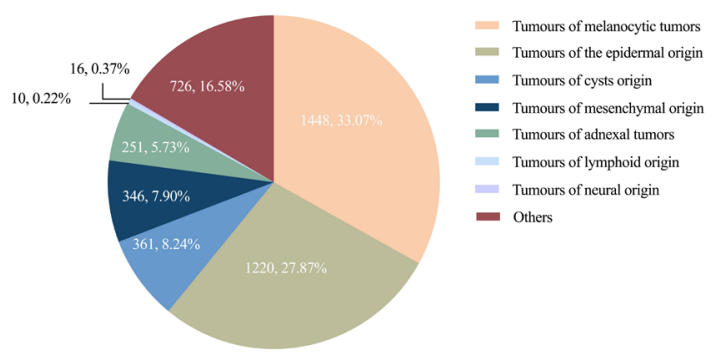

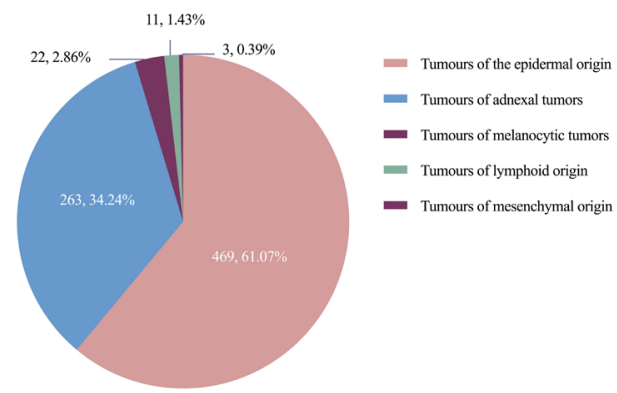

Figure 1 Histogenic origin classification of benign and malignant eyelid tumours and tumour-like lesions. (A) Among 4378 benign eyelid neoplasms, there were 1448 tumours of melanocytic origin, 1220 tumours of epidermal origin, 361 tumours of mesenchymal origin, 346 cases of cysts origin, 251 tumours of adnexal origin, 16 cases of neural origin, 10 tumours of lymphoid origin and 726 other types. (B) Among 768 malignant eyelid tumours, there were 469 tumours of epidermal origin, 263 tumours of adnexal origin, 22 tumours of melanocytic origin, 11 tumours of lymphoid origin and 3 tumours of mesenchymal origin.

eyelid tumours, basal cell carcinoma (BCC) occupied nearly half of all cases $(374,48.70 \%)$. The followings are sebaceous gland carcinoma (SGC) $263(34.24 \%)$, squamous cell carcinoma (SCC) 95 (12.37\%), malignant melanoma (MM) 22 (2.86\%) and lymphoma11 (1.43\%).

In general, there was no considerably obvious gender predominance in total malignant eyelid tumours (415 females vs 353 males). When it came about a single type, there were some differences. In BCC, women were nearly $40 \%$ more than men (218 vs 156). The gap of SGC was smaller, 140 females vs 123 males. However, there were relatively fewer women in SCC, MM and lymphoma.

\section{Time trend analysis}

For benign lesions, during the past nineteen years, there were similar increasing trends in both genders (figure 2). The linear regression results over time were $\mathrm{R}^{2}=0.946$ (linear regression, $\mathrm{p}<0.01)$ for male and $\mathrm{R}^{2}=0.914(\mathrm{p}<0.01)$ for female. The absolute number of lesions increased yearly from 2000 to 2018, from 43 cases (20 in male and

Table 2 Histopathological classification of common benign and malignant eyelid tumours (2000-2018)

\begin{tabular}{|c|c|c|c|c|c|c|}
\hline Type of tumour & No & $\begin{array}{l}\text { Percentage } \\
(\%)\end{array}$ & $\begin{array}{l}\text { Age } \\
\text { (years, range) }\end{array}$ & $\begin{array}{l}\text { Gender ratio } \\
\text { (female/male) }\end{array}$ & $\begin{array}{l}\text { Laterality* } \\
\text { (R/L/B) }\end{array}$ & $\begin{array}{l}\text { Location* } \\
\text { (U/L/B) }\end{array}$ \\
\hline Total & 5146 & & $52.8319 .7(1-106)$ & $5146(3160 / 1986)$ & $2580 / 2456 / 19$ & $2275 / 2302 / 14$ \\
\hline Benign eyelid tumours & 4378 & 100 & $49.6 \pm 18.8(1-106)$ & $1.7: 1(2745 / 1633)$ & $2178 / 2105 / 17$ & 2069/1906/12 \\
\hline Nevus & 1448 & 33.07 & $45.5 \pm 15.1(4-97)$ & 3.6:1 (1134/314) & $741 / 678 / 5$ & $661 / 638 / 6$ \\
\hline $\begin{array}{l}\text { Squamous cell } \\
\text { papilloma }\end{array}$ & 539 & 12.31 & $52.7 \pm 18.8(8-101)$ & $1.1: 1(286 / 253)$ & $263 / 266 / 3$ & $220 / 227 / 2$ \\
\hline Basal cell papilloma & 418 & 9.55 & $62.3 \pm 16.1(11-106)$ & 1.2:1 (224/194) & $202 / 211 / 1$ & $148 / 229 / 1$ \\
\hline Epidermal cyst & 238 & 5.44 & $51.9 \pm 18.9(12-87)$ & $1.1: 1(125 / 113)$ & $107 / 127 / 0$ & $138 / 62 / 0$ \\
\hline Haemangioma & 209 & 4.77 & $46.0 \pm 18.3(7-90)$ & $1.1: 1(110 / 99)$ & $104 / 100 / 0$ & $112 / 68 / 0$ \\
\hline Wart & 108 & 2.47 & $54.3 \pm 22.2(3-95)$ & $1.3: 1(60 / 48)$ & $49 / 56 / 2$ & $54 / 40 / 0$ \\
\hline Calcified epithelioma & 100 & 2.28 & $26.8 \pm 16.6(3-81)$ & $2.0: 1(66 / 34)$ & $58 / 38 / 0$ & $74 / 15 / 0$ \\
\hline Chalazion & 81 & 1.85 & $54.0 \pm 23.1(7-96)$ & $1.0: 1(41 / 40)$ & $44 / 35 / 0$ & $37 / 33 / 0$ \\
\hline Xanthoma & 77 & 1.76 & $48.1 \pm 11.5(19-72)$ & $3.0: 1(58 / 19)$ & $28 / 38 / 3$ & $61 / 3 / 0$ \\
\hline Soft fibroma & 46 & 1.05 & $53.8 \pm 15.7(15-87)$ & $1.2: 1(25 / 21)$ & $29 / 34 / 0$ & $35 / 20 / 0$ \\
\hline Malignant eyelid tumours & 768 & 100 & $71.2 \pm 13.9(16-101)$ & $1.2: 1(415 / 353)$ & $402 / 351 / 2$ & $206 / 396 / 2$ \\
\hline $\mathrm{BCC}$ & 374 & 48.70 & $70.8 \pm 12.4(32-99)$ & $1.4: 1(218 / 156)$ & $187 / 182 / 1$ & $40 / 252 / 0$ \\
\hline SGC & 263 & 34.24 & $71.1 \pm 15.2(16-101)$ & $1.1: 1(140 / 123)$ & $150 / 111 / 0$ & $112 / 72 / 0$ \\
\hline SCC & 95 & 12.37 & $74.0 \pm 13.6(31-100)$ & $0.8: 1(41 / 54)$ & $46 / 49 / 0$ & $27 / 46 / 0$ \\
\hline MM & 22 & 2.86 & $71.3 \pm 16.4(24-93)$ & $0.8: 1(10 / 12)$ & $12 / 9 / 1$ & $7 / 5 / 1$ \\
\hline Lymphoma & 11 & 1.43 & $59.6 \pm 16.3(36-91)$ & $0.6: 1(4 / 7)$ & $6 / 4 / 0$ & $8 / 1 / 0$ \\
\hline
\end{tabular}

${ }^{*}$ Total number of laterality and location are not equal to $100 \%$ of cases because of incomplete information.

BCC, basal cell carcinoma; MM, malignant melanoma; R/L/B, Right eyelid/ Left eyelid/ Both right and left eyelids; SCC, squamous cell carcinoma; SGC, sebaceous gland carcinoma; U/L/B, Upper eyelid/ Lower eyelid/ Both upper and lower eyelids. 

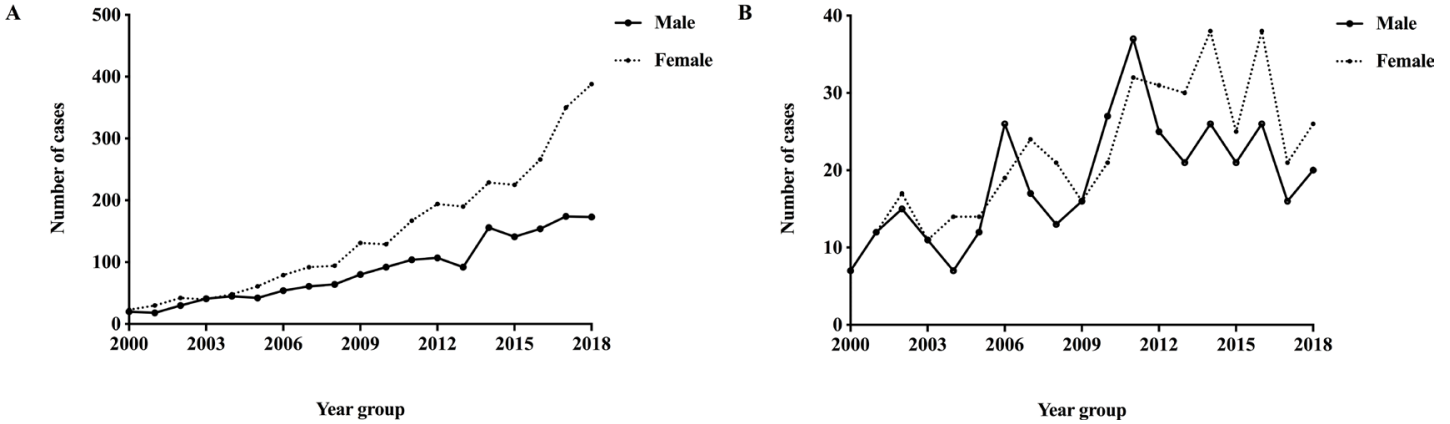

Figure 2 Year distribution of benign and malignant eyelid tumours from 2000 to 2018. (A) Distribution of males and females of benign eyelid tumours from 2000 to 2018. (B) Distribution of males and females of malignant eyelid tumours from 2000 to 2018.

23 in female) in 2000, to 561 cases (173 in male and 388 in female) in 2018. From 2000 to 2018, the annual rise for females was $83.5 \%$, compared with only $40.1 \%$. in males. But for malignant lesions, the linear regression results over time were $\mathrm{R}^{2}=0.310(\mathrm{p}<0.01)$ for male and $\mathrm{R}^{2}=0.595$ $(p<0.01)$ for female. The total number of both genders were both increasing up to 2012, thereafter the proportion of female patients expanded disproportionately.

\section{Age group}

Like shown in figure 3: In all age groups, and in all diagnostic categories female patients outnumbered male patients throughout the course of the study. For benign lesions, more than $33.60 \%(1471 / 4378)$ occurred in patients younger than 40 years and decreased with advancing age. By contrast, very few malignant tumours $(17,2.21 \%)$ happened in patients before 40 years and most cases occurred in old people. The incidence numbers went up with age and reached a peak in 60-70 age group. Females presented more often with malignant tumours than males in all age groups, but this disparity was not as marked as it was for benign eyelid lesions.

Notably, the mean age of patients in BCC, SGC, SCC and $\mathrm{MM}$ were all over 70 years, whereas $59.6 \pm 16.3$ years in lymphoma. The mean age of lymphoma was significantly younger than other malignant types $(\mathrm{p}=0.019)$.

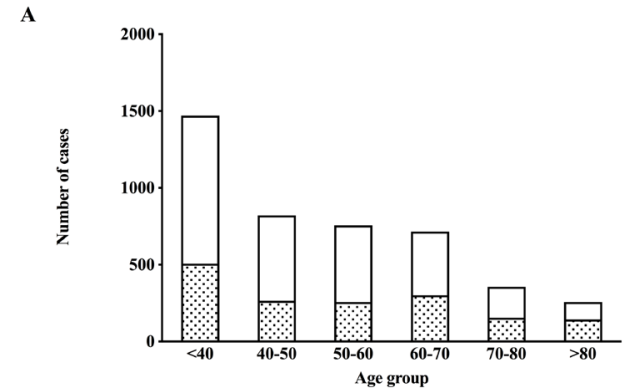

\section{Tumour location}

Benign eyelid lesions occurred a little more in upper eyelids ( $\mathrm{n}=2069,47.3 \%)$ than lower eyelids $(\mathrm{n}=1906$, $43.5 \%$ ), whereas malignant eyelid tumours occurred slightly higher in the lower eyelid $(n=396,51.5 \%)$ than the upper eyelid ( $n=206,26.9 \%$ ) (table 2). In benign lesions, 8 of 10 most common lesions occurred more in upper eyelids. Notably, haemangioma was nearly double in upper eyelids vs lower eyelids (112 cases vs 68 cases); calcified epithelioma was five times ( 74 cases vs 15 cases). For xanthoma, the ratio was extremely around 20 times (61 cases vs three cases). For malignant cancers, BCC showed a significant dominance for the lower eyelid $(\mathrm{n}=252,86.3 \%)$. But for SGC, the ratio between upper and lower eyelids was 1.5 (112 cases vs 72 cases).

\section{Malignant eyelid tumours constitution and SDI}

We also investigated the relationship between the constitution of malignant eyelid tumours and SDI (the median year of study) by reviewing previous literature (table 3 ). The trend was presented in figure 4 . The percentage of BCC was remarkably higher in the countries with higher SDI, ranged from $37.6 \%$ with an SDI of 0.29 in Shanghai, China, to $86 \%$ with an SDI of 0.85 in Switzerland and $90.8 \%$ in Minnesota, America with an SDI of 0.79 . Whereas, SGC, SCC and MM showed an opposite

B

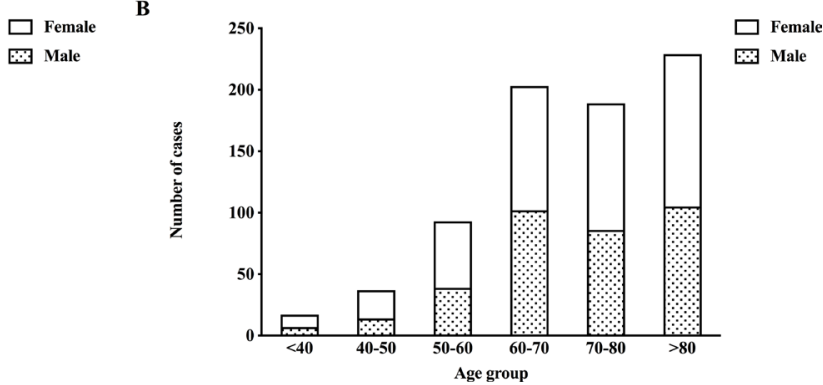

Figure 3 Age distribution of benign and malignant eyelid tumours from 2000 to 2018. (A) Distribution of males and females of benign eyelid tumours in different age groups. (B) Distribution of males and females of malignant eyelid tumours in different age groups. In all age groups, the female had a higher number of cases than their male counterparts for the past 19 years both in benign and malignant tumours. For benign lesions, more than 33.60\% (1471/4378) were made up by patients younger than 40 years. The number of patients undergone surgery of benign lesions went down with age. By contrast, very few malignant tumours $(17,2.2 \%)$ happened in patients before 40 years and most cases occurred in older people and reached a peak in 60-70 age group. 
Table 3 The relative frequencies of benign and malignant eyelid tumours in China

\begin{tabular}{|c|c|c|c|c|c|c|c|}
\hline $\begin{array}{l}\text { District } \\
\text { author }\end{array}$ & $\begin{array}{l}\text { South China, } \\
\text { Ye et al } \\
\text { (present } \\
\text { study) }\end{array}$ & $\begin{array}{l}\text { Shanghai, } \\
\mathrm{Ni}^{15}\end{array}$ & $\begin{array}{l}\text { Beijing, } \\
\text { Xu et } \text { al }^{16}\end{array}$ & $\begin{array}{l}\text { Beijing, } \\
\text { Dai et } \text { al }^{14}\end{array}$ & $\begin{array}{l}\text { Tianjin, } \\
\text { Yu et al }{ }^{17}\end{array}$ & $\begin{array}{l}\text { Taiwan, } \\
\text { Huang et al }{ }^{19}\end{array}$ & $\begin{array}{l}\text { Hong Kong, } \\
\text { Ho et } a^{12}\end{array}$ \\
\hline Total no & 5146 & 3510 & 2639 & 5313 & 2228 & 4521 & 198 \\
\hline $\begin{array}{l}\text { Benign tumours, } \\
\mathrm{n}(\%)\end{array}$ & $\begin{array}{l}4378 \\
(85.1)\end{array}$ & $\begin{array}{l}2365 \\
(67.4)\end{array}$ & $\begin{array}{l}2276 \\
(86.2)\end{array}$ & $\begin{array}{l}4353 \\
(81.9)\end{array}$ & $\begin{array}{l}1910 \\
(85.7)\end{array}$ & $\begin{array}{l}4294 \\
(95.0)\end{array}$ & $\begin{array}{l}170 \\
(86.0)\end{array}$ \\
\hline $\begin{array}{l}\text { Squamous cell } \\
\text { papilloma (\%) }\end{array}$ & 12.3 & 27.9 & 13.5 & 3.8 & 13.0 & 3.4 & - \\
\hline $\begin{array}{l}\text { Basal cell } \\
\text { papilloma (\%) }\end{array}$ & 9.6 & - & 2.7 & 3.2 & 13.7 & 12.6 & 14.7 \\
\hline $\begin{array}{l}\text { Epidermal cyst } \\
(\%)\end{array}$ & 5.5 & 18.1 & 7.4 & 9.9 & 11.5 & 8.2 & 8.2 \\
\hline $\begin{array}{l}\text { Malignant } \\
\text { tumours, n (\%) }\end{array}$ & $\begin{array}{l}768 \\
(14.9)\end{array}$ & $\begin{array}{l}1145 \\
(32.6)\end{array}$ & $\begin{array}{l}363 \\
(13.8)\end{array}$ & $\begin{array}{l}960 \\
(18.1)\end{array}$ & $\begin{array}{l}292 \\
(13.1)\end{array}$ & $\begin{array}{l}227 \\
(5.0)\end{array}$ & $\begin{array}{l}28 \\
(14.0)\end{array}$ \\
\hline $\mathrm{BCC}(\%)$ & 48.7 & 37.6 & 41.3 & 37.0 & 56.5 & 57.8 & 42.9 \\
\hline SGC (\%) & 34.2 & 31.7 & 38.6 & 30.6 & 34.6 & 21.1 & 7.1 \\
\hline $\operatorname{SCC}(\%)$ & 12.4 & 18.9 & 5.0 & 8.0 & 3.8 & 10.1 & 17.9 \\
\hline MM (\%) & 2.9 & 4.9 & 4.4 & 2.7 & 1.4 & 3.5 & 7.1 \\
\hline Others (\%) & 1.4 & 1.8 & 1.7 & 1.6 & 1.7 & 7.5 & 3.6 \\
\hline
\end{tabular}

BCC, basal cell carcinoma; MM, malignant melanoma; SCC, squamous cell carcinoma; SGC, sebaceous gland carcinoma.

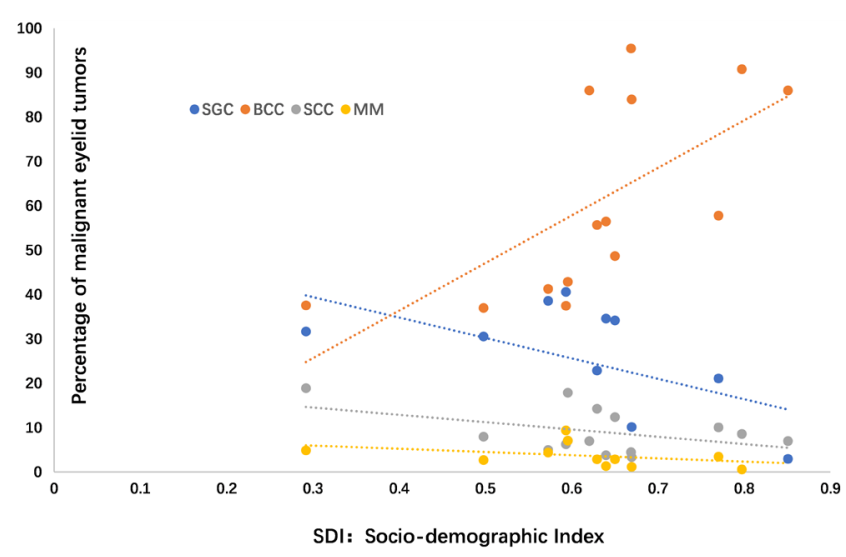

Figure 4 The linear regression of common malignant eyelid tumours constitution and SDI. The constitution of malignant eyelid tumours were based on previous literature review. The included SDI was the median year of certain study. The areas with higher SDI showed higher percentage of BCC, but relatively decreased constitution of SGC. The percentage of SCC and MM remains relatively stable. BCC, basal cell carcinoma; MM, malignant melanoma; SCC, squamous cell carcinoma; SDI, sociodmographic Index; SGC, sebaceous gland carcinoma. distribution trends that the relative constitution decreased in higher SDI countries.

\section{DISCUSSION}

To our knowledge, this study is one of the largest clinicopathological analysis of eyelid tumours and tumourlike lesions worldwide. In our study, benign eyelid lesions occurred more often in the upper eyelid and malignant eyelid tumours occurred more commonly in the lower eyelid. The proportion of benign lesions was similar to other studies which reported them to represent between $58.8 \%$ and $95.0 \%$ of all eyelid tumours..$^{2121416}$ In contrast, Bagheri's study carried out in Teheran found a higher proportion of malignant eyelid tumours. ${ }^{9}$ The inclusion criteria, difference in geographical and climate location as well as the hospital care referral system may explain this disparity. Tables 3 and 4 illustrate comparison of proportion of benign and malignant eyelid tumours in different regions of China as well as other countries. We hypothesised that the different incidences of eyelid tumours in various regions and countries were mainly decided by differences of skin colour, race, severity and sensitivity to sunshine exposure, as well as socioeconomic 


\begin{tabular}{|c|c|c|c|c|c|c|c|}
\hline $\begin{array}{l}\text { District } \\
\text { Author }\end{array}$ & $\begin{array}{l}\text { Singapore } \\
\text { Lee }^{6}\end{array}$ & $\begin{array}{l}\text { Japan } \\
\text { Takamura }^{25}\end{array}$ & $\begin{array}{l}\text { Thailand } \\
\text { Pornpanich }^{13}\end{array}$ & $\begin{array}{l}\text { Turkey } \\
\text { Gundogan } \\
\end{array}$ & $\begin{array}{l}\text { Greece } \\
\text { Asproudis }^{20}\end{array}$ & $\begin{array}{l}\text { Switzerland } \\
\text { Deprez }^{2}\end{array}$ & $\begin{array}{l}\text { USA } \\
\text { Cook }^{5}\end{array}$ \\
\hline Period & 1968-1995 & 1986-2003 & 2000-2004 & 2008-2012 & 1983-2012 & 1989-2007 & $1976-1990$ \\
\hline Total no & 325 & 38 & 297 & 1541 & 851 & 5504 & 174 \\
\hline $\begin{array}{l}\text { Benign tumours, } \\
\mathrm{n}(\%)\end{array}$ & - & - & $\begin{array}{l}212 \\
(71.4)\end{array}$ & $\begin{array}{l}1426 \\
(92.5)\end{array}$ & $\begin{array}{l}500 \\
(58.8)\end{array}$ & $\begin{array}{l}4610 \\
(84)\end{array}$ & - \\
\hline Nevus (\%) & - & - & 52.8 & 17.6 & 13 & 20 & - \\
\hline $\begin{array}{l}\text { Squamous cell } \\
\text { papilloma (\%) }\end{array}$ & - & - & 22.2 & 21.8 & 13 & 26 & - \\
\hline $\begin{array}{l}\text { Basal cell } \\
\text { papilloma (\%) }\end{array}$ & - & - & 13.2 & 17.3 & 18 & 21 & - \\
\hline $\begin{array}{l}\text { Epidermal cyst } \\
(\%)\end{array}$ & - & - & 1.9 & 7.2 & 20 & 11 & - \\
\hline $\begin{array}{l}\text { Malignant tumours, } \\
\mathrm{n}(\%)\end{array}$ & 325 & 38 & $\begin{array}{l}32 \\
(10.8)\end{array}$ & $\begin{array}{l}22 \\
(1.5)\end{array}$ & $\begin{array}{l}351 \\
(41.2)\end{array}$ & $\begin{array}{l}894 \\
(16)\end{array}$ & 174 \\
\hline BCC (\%) & 84.0 & 39.5 & 37.5 & 95.5 & 86 & 86 & 90.8 \\
\hline SGC (\%) & 10.2 & 28.9 & 40.6 & - & & 3 & - \\
\hline $\operatorname{SCC}(\%)$ & 3.4 & 10.5 & 6.3 & 4.5 & 7 & 7 & 8.6 \\
\hline MM (\%) & 1.2 & 7.9 & 9.4 & - & & - & 0.6 \\
\hline Others (\%) & 1.2 & 13.1 & 6.3 & - & & 4 & - \\
\hline
\end{tabular}

BCC, basal cell carcinoma; MM, malignant melanoma; SCC, squamous cell carcinoma; SGC, sebaceous gland carcinoma.

factors which affects patient's lifestyle and willingness to undergo surgical excision.

The most common benign eyelid tumour in this study was pigmented nevus $(33.1 \%)$ which also was the most common benign eyelid tumour among many Asian populations. ${ }^{9} 1012-1416{ }^{19}$ Some previous reports in China ${ }^{14-16}$ found a lower frequency of nevus. This may reflect the more recent improving socioeconomic status in China which has allowed patients to seek removal of these lesions for cosmetic reasons. The greater proportion of female patients with nevi (3.6/1) might arguably reflect a greater cosmetic motivation among females. The mean age at surgery 49.6 years is close to 49 years in Greece ${ }^{20}$ and 54 years in Hong Kong. ${ }^{12}$ More than $33.60 \%$ of benign lesions occurred in patients younger than 40 years and the number of benign lesions decreased with advancing age suggesting that cosmetic consideration might be a more important factor motivating younger patients. Another possible influencing factor is the eye health problems associated with eye makeup. Younger women tend to use makeup which might change the secretion of glands and has other chronic stimulation to eyelid skin. ${ }^{21}$

In our study, BCC was the most common eyelid malignancy $(\mathrm{n}=374,48.7 \%)$ and occurred more often in the lower eyelid (40 upper vs 252 lower eyelids). It occurred more often among women (218 females vs 156 males), which is consistent with previous studies of both Caucasians ${ }^{22} 23$ and Asians. ${ }^{6} 12192425$ The average age $70.8 \pm 12.4$ years was consistent with previous reports too. ${ }^{9}{ }^{10}{ }^{26}$ However, the composition of BCC among malignant eyelid lesions was lower in Asian ${ }^{12}$ 14-16 $19^{25}$ than
non-Asian populations. ${ }^{9}$ The large difference between Caucasians and Asians, we hypothesised it was decided by skin colour, genetic background and sensitivity to sun exposure. UV exposure is the predominant risk factor for BCC, ${ }^{27}$ so light-skinned population are more likely to be infringed as it's decided by genetic predisposition. Fitzpatrick ${ }^{2829}$ developed a skin colour classification to predict susceptibility to actinic damage-ranging from type I with highest risk of actinic damage to type VI with lowest risk. The Caucasian had the lightest skin colour (type I-III), and proportionately greater risk of actinic damages induced BCCs. Up to two-thirds of BCCs occurred in the lower eyelid. ${ }^{530}$ There exists a well-established relationship between BCC and the pilosebaceous unit. ${ }^{31}$ The higher predominance of lower eyelid was resulted from more pilo-sebaceous units in the lower eyelids.

For great differences of BCC among Asians, we initially hypothesised it was caught by different socioeconomic situations especially when we saw the curve of BCC in figure 4, but it was atypical in our own cohort. People from Hong Kong, ${ }^{12}$ Taiwan $^{32}$ despite they share the similar genetic background with Mainland Chinese, but they have a much higher percentage of BCC. Another distinct example was Singapore, ${ }^{6}$ of which $76.2 \%$ citizen population are ethnic Chinese but showed nearly double likelihood of BCC incidence (84\% of total malignant cancers) comparing with Mainland China. Initially, we supposed that areas with better socioeconomic status will have higher incidence of BCC, as most western countries have higher BCC proportion too. The boost of economy will prolong life expectancy which inevitably accompany 
with the accumulation of carcinogenic factors, ${ }^{27}$ and then increased the UV-exposure-related damage. However, there was no significant changes of cancer constitution over past 19 years in our hospital during which period gross domestic product per capita of Zhejiang Province increased from US\$1916 in 2000 to US\$14 086 in $2018 . .^{33}$ But any impact of socioeconomic improvement would take much longer to show up. So, we still attribute it to the combined work of gene and environment factors like UV-exposure. Taiwan, Hongkong, Singapore are at a lower latitude with greater sun exposure resulting in higher percentage of BCC.

SGC and SCC of are proportionally less common in light-skinned populations ${ }^{1} 182728$ while proportionally more common in Asians. ${ }^{13} 151625$ This disproportionate infrequency is most pronounced for SGC which is a very rare (fewer than 5\%) in Europe ${ }^{2}$ or America, ${ }^{5}$ but among the most common malignancy in Asia (up to 40\%). Sihota ${ }^{34}$ reported that SGC was the most common malignant eyelid tumour in India $(36.7 \%)^{34}$ and Pornpanich ${ }^{13}$ in Thailand reported $40.6 \%$ separately which is also close to our study. A multicentre study ${ }^{35}$ also showed there was no higher incidence rate of SGC in Taiwanese than white populations based on data from cancer registries. We still suspect that it is related to the differential distribution of Fitzpatrick skin types ${ }^{28}$ among these study populations. Most Indians range between Fitzpatrick skin types IIIVI and the majority are type IV. ${ }^{36}$ Southeast Asians like Chinese $^{37}$ are principally type III (more than $70 \%$ ). So, the greater of Fitzpatrick grades lead to lower incidence of UV-induced cancer like BCC, then make the proportions of SGCs and SCCs relatively higher.

SGCs are more common in the upper eyelid, which is likely to be related to the higher distribution of Meibomian glands in those areas. ${ }^{31}$ The youngest patient of SGC in our study in only 16 years which was younger than BCC (32 years) or SCC (31 years). Considering the potential lethality of SGC, it reminds us that we should pay special attention to Asian patients even at younger age. We also saw an interesting phenomenon that more SGC were occurred on right eye (Right 150/Left 111) which was not reported by others.

The incidence proportion of SCC is different in many regions and countries. ${ }^{5} 61213163839$ In our study, SCC accounted for only $12.37 \%$ in total cases with male predominance ( 54 males vs 41 females) which is a very interesting gender inequality as BCC, SGC were more frequent in female. Other previous studies also found a greater male predominance of SCC, either in whole body skin cancer ${ }^{40}$ or the oral tongue. ${ }^{41}$ And eyelid SCC is more common in lower eyelid than upper (46 vs 27 cases) which is consistent with previous reports, but not as obvious as them. A study from Minnesota reported nine cases in lower lids with only one in upper. ${ }^{5}$ Another study from Australia found on the lower lid in 31 cases, upper lid in five cases. ${ }^{42}$

The number of both malignant and benign eyelid lesions increased on an annual basis during most of the study period (figure 2), but the number of female patients increased significantly relative to males over time. The increase of malignant eyelid cancers was not as pronounced as benign lesions, but shared similar distribution in both genders. This increase may reflect the growth in outpatients of our hospital and increase in the population in Zhejiang Province. But the disproportionate increase in benign lesions in females may reflect increasing opportunities for women to seek treatment for removal of benign lesions they consider to be unsightly. This inequality also might reflect women's increasing use of makeup with improved socioeconomic situation. The number malignant cancers reached its peak around 2012 , then became quite stable even had a small decrease in 2015. It's explainable that we set up oculoplastic sub-specialty around 2012 and other ophthalmologists stopped to do the surgery with eyelid cancers which caused first decrease. However, our study still has some inherent limitations. First, all patients were recruited from a single centre and not based on the entire community population. As a retrospective study, it's also limited in terms of recall of patients and pathological rigour. This might make our findings skewed. In some difficult cases without a final certain diagnosis (fewer than 1\%) might have an influence on the statistical results of laterality and location. More importantly, the explanation for variations of malignant cancers is merely based on speculation, needs further mechanism investigation.

In conclusion, our study provides a large-scale, comprehensive description of the spectrum of eyelid tumours seen in South China over the past 19 years. It is hoped that this information will allow clinicians to make better diagnosis, reduce misdiagnosis and benefit clinical treatment. The spectrum of disease is not only decided by race, skin, sensitivity to UV-exposure, but also might be influenced by socioeconomic status.

Acknowledgements We thank the Pathologists, Dr Lirong Chen and Dr Fengbo Huang, for their unselfish assistance with pathology guidance of this paper.

Contributors LW, YS, TG and JY were responsible for study design and LW, YS, $X D, J S, X P$ and $N Y$ for data collection. LW and YS analysed the data. LW, TG and $J Y$ drafted the paper. All authors read, commented on and approved the final manuscript.

Funding The study was supported by the National Key Research and Development Program of China (2019YFC0118401) and the National Natural Science Foundation of China (Grant No 81670888).

Competing interests None declared.

Patient consent for publication Not required.

Ethics approval Ethical approval for the study was obtained from Ethics Committee of the Second Affiliated Hospital, Zhejiang University School of Medicine (No. Y2019-195) and the study adhered to the Declaration of Helsinki.

Provenance and peer review Not commissioned; externally peer reviewed.

Data availability statement All data relevant to the study are included in the article. No additional data available.

Open access This is an open access article distributed in accordance with the Creative Commons Attribution Non Commercial (CC BY-NC 4.0) license, which permits others to distribute, remix, adapt, build upon this work noncommercially, and license their derivative works on different terms, provided the original work is properly cited, appropriate credit is given, any changes made 
indicated, and the use is non-commercial. See: http://creativecommons.org/ licenses/by-nc/4.0/.

\section{ORCID iDs}

Linyan Wang http://orcid.org/0000-0001-8316-6994

Yi Shan http://orcid.org/0000-0002-1116-6191

Juan Ye http://orcid.org/0000-0002-1948-2500

\section{REFERENCES}

1 Cook BE, Bartley GB. Treatment options and future prospects for the management of eyelid malignancies: an evidence-based update. Ophthalmology 2001;108:2088-98.

2 Deprez M, Uffer S. Clinicopathological features of eyelid skin tumors. A retrospective study of 5504 cases and review of literature. Am J Dermatopathol 2009;31:256-62.

3 Shields JA, Demirci H, Marr BP, et al. Sebaceous carcinoma of the eyelids: personal experience with 60 cases. Ophthalmology 2004;111:2151-7.

4 Actis AG, Actis G, De Sanctis U, et al. Eyelid benign and malignant tumors: issues in classification, excision and reconstruction. Minerva Chir 2013;68:11-25.

5 Cook BE, Bartley GB. Epidemiologic characteristics and clinical course of patients with malignant eyelid tumors in an incidence cohort in Olmsted County, Minnesota. Ophthalmology 1999;106:746-50.

6 Lee SB, Saw SM, Au Eong KG, et al. Incidence of eyelid cancers in Singapore from 1968 to 1995. Br J Ophthalmol 1999;83:595-7.

7 Mak ST, Wong AC-M, lo IY-F, et al. Malignant eyelid tumors in Hong Kong 1997-2009. Jpn J Ophthalmol 2011;55:681-5.

8 Kersten RC, Ewing-Chow D, Kulwin DR, et al. Accuracy of clinical diagnosis of cutaneous eyelid lesions. Ophthalmology 1997;104:479-84.

9 Bagheri A, Tavakoli M, Kanaani A, et al. Eyelid masses: a 10-year survey from a tertiary eye hospital in Tehran. Middle East Afr J Ophthalmol 2013;20:187-92.

10 Chang C-H, Chang S-M, Lai Y-H, et al. Eyelid tumors in southern Taiwan: a 5-year survey from a medical university. Kaohsiung J Med Sci 2003;19:549-53.

11 Gundogan FC, Yolcu U, Tas A, et al. Eyelid tumors: clinical data from an eye center in Ankara, Turkey. Asian Pac J Cancer Prev 2015;16:4265-9.

12 Ho M, Liu DTL, Chong KKL, et al. Eyelid tumours and Pseudotumours in Hong Kong: a ten-year experience. Hong Kong Med J 2013;19:150-5.

13 Pornpanich K, Chindasub P. Eyelid tumors in Siriraj Hospital from 2000-2004. J Med Assoc Thai 2005;88 Suppl 9:S11-14.

14 Dai J, Sun X, Li B, et al. [Histopathology studies on 8,673 cases of ocular adnexal hyperplastic lesions and tumors]. Zhonghua Yan Ke Za Zhi 1999;35:258-61.

$15 \mathrm{Ni}$ Z. [Histopathological classification of 3,510 cases with eyelid tumor]. Zhonghua Yan Ke Za Zhi 1996;32:435-7.

$16 \mathrm{Xu}$ X-lin, Li B, Sun X-li, et al. [Clinical and pathological analysis of 2639 cases of eyelid tumors]. Zhonghua Yan Ke Za Zhi 2008;44:38-41.

17 Yu S-S, Zhao Y, Zhao H, SS Y, Zhao H, et al. A retrospective study of 2228 cases with eyelid tumors. Int J Ophthalmol 2018;11:1835-41.

18 Elder DE, Massi D, Scolyer RA. WHO classification of skin tumours: international agency for research on cancer 2018.

19 Huang Y-Y, Liang W-Y, Tsai C-C, et al. Comparison of the clinical characteristics and outcome of benign and malignant eyelid tumors: an analysis of 4521 eyelid tumors in a tertiary medical center. Biomed Res Int 2015;2015:1-5

20 Asproudis I, Sotiropoulos G, Gartzios C, et al. Eyelid tumors at the University eye clinic of loannina, Greece: a 30-year retrospective study. Middle East Afr J Ophthalmol 2015;22:230-2.

21 Okura M, Kawashima M, Katagiri M, et al. New eye cleansing product improves Makeup-Related ocular problems. J Ophthalmol 2015;2015:831628:1-7.

22 Swanson MW, Cloud G. A retrospective analysis of primary eye cancer at the University of Alabama 1958-1988. Part 2: eyelid tumors. J Am Optom Assoc 1991;62:820-3.

23 Tesluk GC. Eyelid lesions: incidence and comparison of benign and malignant lesions. Ann Ophthalmol 1985;17:704-7.

24 Nithithanaphat C, Ausayakhun S, Wiwatwongwana D, et al. Histopathological diagnosis of eyelid tumors in Chiang Mai university hospital. J Med Assoc Thai 2014;97:1096-9.

25 Takamura $\mathrm{H}$, Yamashita $\mathrm{H}$. Clinicopathological analysis of malignant eyelid tumor cases at Yamagata university hospital: statistical comparison of tumor incidence in Japan and in other countries. Jpn J Ophthalmol 2005;49:349-54.

26 Wang J-K, Liao S-L, Jou J-R, et al. Malignant eyelid tumours in Taiwan. Eye 2003;17:216-20.

27 Kraft S, Granter SR. Molecular pathology of skin neoplasms of the head and neck. Arch Pathol Lab Med 2014;138:759-87.

28 Taylor SC. Skin of color: biology, structure, function, and implications for dermatologic disease. J Am Acad Dermatol 2002;46:S41-62

29 Fitzpatrick TB. The validity and practicality of sun-reactive skin types I through VI. Arch Dermatol 1988;124:869-71.

30 Doxanas MT, Green WR, lliff CE. Factors in the successful surgical management of basal cell carcinoma of the eyelids. Am J Ophthalmol 1981;91:726-36.

31 Pe'er J. Pathology of eyelid tumors. Indian J Ophthalmol 2016;64:177-90.

32 Lin H-Y, Cheng C-Y, Hsu W-M, et al. Incidence of eyelid cancers in Taiwan: a 21-year review. Ophthalmology 2006;113:2101-7.

33 Wang L, Chen L, Dai X. A clinicopathological classification analysis of ocular mass lesions in 7910 cases. Chinese Journal of Ophthalmology 2019;55:847-53.

34 Sihota Ret al. Malignant eyelid tumors in an Indian population. Arch Ophthal 1996;114:108-9.

35 Wu A, Rajak SN, Chiang Chun-Ju, et al. Epidemiology of cutaneous sebaceous carcinoma. Australas J Dermatol 2020.

36 Agarwal M, Velaskar S. Laser Skin Rejuvenation With Fractional 1064 Q-switched Nd:YAG In 252 Patients: An Indian Experience. J Cosmet Dermatol 2019.

37 Liu W, Lai W, Wang XM, et al. Skin phototyping in a Chinese female population: analysis of four hundred and four cases from four major cities of China. Photodermatol Photoimmunol Photomed 2006;22:184-8.

38 Chen R-J, Xiao Y-Q. [Clinical and pathological analysis of 2734 cases of eyelid neoplasms]. Zhonghua Yan Ke Za Zhi 2008;44:143-6.

39 Cheng C-Y, Hsu W-M. Incidence of eye cancer in Taiwan: an 18-year review. Eye2004;18:152-8.

40 Nasser N, Nasser Filho N, Lehmkuhl RL. Squamous cell cancer--31year epidemiological study in a city of south Brazil. An Bras Dermatol 2015;90:21-6.

41 Saba NF, Goodman M, Ward K, et al. Gender and ethnic disparities in incidence and survival of squamous cell carcinoma of the oral tongue, base of tongue, and tonsils: a surveillance, epidemiology and end results program-based analysis. Oncology 2011;81:12-20.

42 Donaldson MJ, Sullivan TJ, Whitehead KJ, et al. Squamous cell carcinoma of the eyelids. Br J Ophthalmol 2002;86:1161-5. 